\title{
Rehberlik ve Araştırma Merkezleri Denetim Rehberinin Incelenmesi
}

\author{
Doç. Dr. Osman Ferda Beytekin \\ Ege Üniversitesi-Türkiye \\ beytekin.ferda@gmail.com
}

\author{
Elif Kaynar (Y.L.öğr) \\ Milli Eğitim Bakanlığı-Türkiye \\ elf.kaynar@gmail.com
}

\begin{abstract}
Özet:
Bu araştırmanın amacı Rehberlik ve Araştırma Merkezleri Rehberlik ve Denetim Rehberini yasal belgeler ve alanyazın temelinde incelemektir. Araştırmada nitel araştırma yöntemlerinden biri olan döküman incelemesi modeli kullanılmıştır. Araştırmanın çalışma dökümanını Rehberlik ve Araştırma Merkezleri Rehberlik ve Denetim Rehberi oluşturmaktadır. Veriler içerik analizi tekniği ile analiz edilmiştir. Araştırmanın bulguları incelendiğinde; rehberin gönderme yapmış olduğu Rehberlik ve Psikolojik Danışma Hizmetleri Yönetmeliğinin ve Özel Eğitim Hizmetleri Yönetmeliğinin güncel olmadığı ve içeriğindeki "Verilecek hizmetin niteliğine göre çeşitli psikolojik ölçme araçlarının bilimsel standartlarına göre uygulanması (MEB Rehberlik ve Psikolojik Danışma Hizmetleri Yönetmeliği Md. 30/d)" maddesinin yürürlükten kaldırıldığı tespit edilmiştir. Bu bulgu rehberdeki tutarsızlığın temel nedeni olarak yorumlanabilir. Rehberlik ve Araştırma Merkezleri Rehberlik ve Denetim Rehberinin, güncel olmamakla birlikte alanyazınla çoğunlukla tutarlı olduğu sonucuna ulaşılmıştır. Bunun dışında, rehberin içeriğinde etik kavramına ve etik değerlerin uygulanmasına ilişkin hiçbir ifadenin bulunmadığı tespit edilmiştir.
\end{abstract}

Anahtar Kelimeler: Eğitim denetimi, Rehberlik ve Araştırma Merkezi (RAM), Denetim rehberi

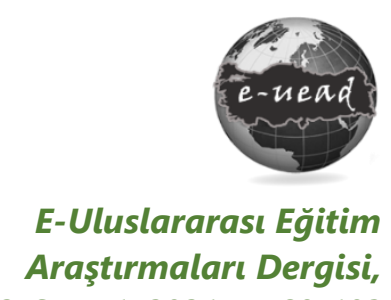

Cilt: 12, Sayı: 1, 2021, ss. 89-103

DOI: 10.19160/ijer.840891

Gönderim : 14.12.2020

Kabul : 04.03.2021

\section{Önerilen Atıf}

Beytekin, O. F. Ve Kaynar, E. (2021). Rehberlik Araştırma Merkezi Denetim Rehberinin Incelenmesi, E-Uluslararası Eğitim Araştırmaları Dergisi, Cilt: 12, Sayı: 1, 2021, ss. 89-103, DOI: 10.19160/ijer.840891 


\section{Giriş}

Denetim, örgütsel eylemlerin, kabul edilen amaçlara yönelik ilke ve kurallara uygun olup olmadığının anlaşııması sürecidir (Aydın, 2014). Denetim sistemi tüm örgütlerde, örgütün amaçlarından uzaklaşmaması için gerekli görülmektedir (Öztürk, 2009). Bir başka açıdan denetim, işleyiş ile ilgili dönütü, düzeltmeyi ve süreci geliştirme çabalarını temel alan, bir sistemin sağlıklı işleyişinin ve sürekli gelişiminin devamlıı̆̆ını sağlayan süreci kapsayan eylemdir (Memduhoğlu \& Zengin, 2011). Denetimin amacı olması gereken standartların belirlenip var olan durumla arasındaki uygunluğun ortaya konulması olarak ifade edilebilir (Toprakçı ve Taş, 2020).

Denetim, örgütsel amaçlar doğrultusunda yapılan çalışmaları denetlemek ve değerlendirmek, örgütsel kaynakların en verimli ve yararlı biçimde kullanılmasını sağlamak için ilgililere önerilerde bulunmak, çalışanların çalışmalarına ve yetişmelerine rehberlik yolu ile yardımda bulunmak gibi geniş bir hizmet alanına sahiptir (Beytekin \& Tas, 2017). Denetim, bir ülkenin tüm kurumlarının ihtiyaç duyduğu bir süreçtir. Toplumun tüm eğitsel faaliyetlerini gerçekleştirme amacı güden eğitim kurumlarının da denetime intiyacı vardır. Bu ihtiyaç, eğitim denetimi alanını doğurmuştur. Eğitim kurumlarının işleyişinin hukuki esaslara dayanması (Toprakçı, Beytekin ve Doğan, 2018) denetimlerini zorunlu kılmaktadır. Okullarda yürütülen eğitim faaliyetlerinin, kontrolsüz olarak sağlıklı biçimde sürdürülmesi mümkün değildir. Eğitim, toplumların kalkınmaları ve ilerlemeleri için önemli olmakla beraber, toplum içerisinde yaşayan bireylerin toplumsal ve bireysel hayata hazırlanabilmeleri ve kişisel gelişimlerini sağlayabilmeleri adına gereklidir. Toplumdaki bireylerin sürekli eğitim almalarına bağlı olarak elde ettikleri bilgi ve becerileri kullanmaları, yaşadıkları ülkedeki kalkınmayı ve mutluluğu sağlamaktadır (Akyol, Yavuzkurt, \& Ulutaş, 2020). Bilgi toplumunda; duyarlı, farkındalığı yüksek ve üretken bireylerin yetişmesi için gerekli olan bilgi ve beceriler sürekli artmaktadır ve böyle bir toplumda geleceğin yetişkinleri olacak çocukların aldığı eğitimin kalitesi oldukça önemlidir (Arslan \& Sayın, 2017). Eğitim uzun bir süreci kapsamaktadır ve bu süre içerisindeki çalışmaların yanlış ya da eksik olarak yapılması uzun dönemde büyük kayıplara neden olabilir. Böylesine önemli bir çalışma alanının sürekli olarak denetim ve gözetim altında tutulması gerekmektedir. Bu bilgiler ışığında, eğitim örgütlerinde denetim sisteminin gerekliliği ve önemi ortaya çıkmaktadır.

Eğitim denetimi, eğitim örgütlerinin hedeflerinin gerçekleşme derecesini saptama, daha iyi sonuçlar elde edebilmek için önlem alma ve süreci etkili ve verimli kılma çabalarının tamamıdır (Toprakçı \& Güngör, 2014). Eğitim denetimi, denetimin işlevlerini, görevlerini gerçekleştirmek suretiyle eğitimin amaçlarının gerçekleşmesine yardımcı olur. Sistem özellikleri açısından denetim; sistemin girdi, işlem ve çıktılarından bilgi alınması, alınan bilgilerin değerlendirilmesi ve değerlendirme sonuçlarına göre örgüt amaçlarının düzeltilmesi ve geliştirilmesi olarak tanımlanabilir (Gökçe, 1994).

Eğitim sisteminin hem girdisi hem de çıktısı olan öğrencinin, farklı özellikleri olabileceği gibi farklı sorunları da olabilmektedir. Bir sistemin en küçük halkasında bir sorun yaşanır ve bu sorun ortadan kaldııımaz ise mevcut sorun tüm sisteme olumsuz olarak yansımaktadır. Bu sorunları fark edebilmek, tüm bireyleri kazanabilmek ve daha büyük problemleri önleyebilmek adına rehberlik faaliyetleri önem taşımaktadır (Seven \& Engin, 2012). Son yıllarda eğitimin denetiminde, insan kaynağından etkili biçimde yararlanılması amacıyla insan kaynaklarına önem verilen rehberliği ön plana alan bir anlayış hakimdir (Sağlam \& Aydoğmuş, 2016).

Türkiye'de eğitim denetimi Milli Eğitim Bakanlığı (MEB) tarafından okul/kurum denetimi olarak yapılmaktadır. Kurum denetimi, eğitim örgütlerinin yönetimini kapsamaktadır ve kurumların sistemindeki yeniliklerin ilgili kurumlara iletilebilmesi, engellerin belirlenmesi, bu engellerin çözümleri, kurum içindeki madde ve insan kaynaklarının verimli kullanılmasının sağlanması, eğitim-öğretim etkinliklerinin geliştirilmesi, öğrenmenin ve yönetimin etkin olması için objektif verilere, yasa, tüzük, yönetmelik, genelge ve kararlara dayalı olarak gözlenmesi, kontrol edilmesi ve değerlendirilerek geliştirilmesidir (Resmi Gazete, 2017). 20. 08. 2017 tarih ve 30160 sayılı MEB Teftiş Kurulu Yönetmeliğine göre; okullardaki kurum denetimleri maarif müfettişleri tarafından gerçekleştirilmektedir (MEB, 2017). Maarif Müfettişleri Teftiş Kurulu Başkanlığı'nın bünyesinde, kurumların kontrol ve denetimini ilgili birimlerle iş birliği içinde 
yapmak, süreç ve sonuçlarını mevzuata, önceden belirlenmiş amaç ve hedeflere, performans ölçütlerine ve kalite standartlarına göre analiz etmek, karşılaştırmak ve ölçmek, kanıtlara dayalı olarak değerlendirmek, elde edilen sonuçları rapor haline getirerek ilgili birimlere ve kişilere iletmek, denetim, inceleme ve soruşturma iş ve işlemlerini ve diğer görevlerini yerine getirmekle yükümlüdür (Resmi Gazete, 2018). Milli Eğitim Bakanlığı Teftiş Kurulu Başkanlığı tarafından, maarif müfettişlerinin görevlerini uygularken esas alacakları yönergeleri içeren denetim rehberleri hazırlanmıştır. Bu araştırmanın çalışma dökümanı, Rehberlik ve Araştırma Merkezleri Rehberlik ve Denetim Rehberidir. Çalışmada, "RAM"; Rehberlik ve Araştırma Merkezleri'ni, "rehber" veya "denetim rehberi" ise Rehberlik ve Araştırma Merkezleri Rehberlik ve Denetim Rehberini ifade etmektedir. 31 Ağustos 2020 tarihinde yayınlanmış olan Milli Eğitim Bakanlığı Rehberlik ve Araştırma Merkezi Yönergesi'ne göre; RAM'lar, il veya ilçelerdeki rehberlik ve psikolojik danışma hizmetleri ile özel eğitim hizmetlerinin planlanması, sunulması, koordineli bir şekilde yürütülmesi, sunulan hizmetlerin izlenmesi ve değerlendirilmesi amacıyla faaliyet yürüten kurumlardır ve rehberlik ve araştırma merkezleri; rehberlik ve psikolojik danışma hizmetleri bölümü ve özel eğitim hizmetleri bölümü olmak üzere iki bölümden oluşmaktadır. Rehberlik kavramı 1950 ile 1960 yılları arasında Türk eğitim sisteminin gündemine girmesine rağmen 24376 sayılı MEB Psikolojik Danışma ve Rehberlik Hizmetleri Yönetmeliği 2001 yılında yayınlanmıştır. 1997 yılında Resmi Gazete'de yayınlanan 573 Sayılı Özel Eğitim Hakkında Kanun Hükmünde Kararname'ye göre Rehberlik ve Araştırma Merkezleri, eğitim öğretim kurumlarındaki rehberlik ve psikolojik danışma hizmetlerinin etkin ve verimli bir şekilde yürütülebilmesine ilişkin gerekli her türlü çalışmaların yanısıra özel eğitim gerektiren bireyleri de tanılamada belirtildiği şekilde inceler, tanılar, yerleştirilebilecekleri en uygun eğitim ortamını önerir ve bu bireylere rehberlik ve psikolojik danışma hizmetleri sunar (Halmatov, 2014). Türkiye'de rehberlik ve psikolojik danışma hizmetlerinin etkin bir şekilde yürütülebilmesi için yükseköğretim kurumları ile ilişki içerisinde olması gerektiği öne sürülmektedir (Aslan \& Bal, 2014).

Bu çalışmanın amacı, Rehberlik ve Araştırma Merkezleri Rehberlik ve Denetim Rehberinin alanyazın bilgisi temelinde analiz edilerek rehberdeki eksikliklerin belirlenmesi ve bu sayede Türkiye'de eğitim denetimi bilimi alanına ve uygulamalarına katkı sunmaktır. Alanyazın incelendiğinde, denetim rehberleri ile ilgili herhangi bir bilimsel çalışmaya ulaşılamamıştır. Bu çalışmanın, alanyazına katkı sunarak bu eksikliği gidereceği, eğitim denetimi alanına denetim rehberleri çerçevesinde katkı sunacağı beklenmektedir. Bu araştırmada, alanyazın ve yasal belgeler çerçevesinde Rehberlik ve Araştırma Merkezleri Rehberlik ve Denetim Rehberinin tutarlıı̆ııın, uygunluğunun ve güncelliğinin incelenmesi amaçlanmaktadır.

\section{YÖNTEM}

\section{Araştırmanın Modeli}

$\mathrm{Bu}$ çalışmada, nitel araştırma desenlerinden biri olan döküman incelemesi yöntemi kullanılmıştır. Döküman incelemesi, dökümanlara ulaşma, dökümanların orjinalliğini kontrol etme, dökümanları anlama, veriyi analiz etme ve kullanma olarak beş aşamadan oluşmaktadır (Yıldırım \& Şimşek, 2018). Doküman incelemesi, hem basılı hem de elektronik materyalleri incelemek veya değerlendirmek için verilerin incelenmesini ve yorumlanmasını gerektirir. Doküman incelemesinde analitik işlem süreci, dokümanlarda yer alan verilerin bulunmasını, seçilmesini, değerlendirilmesini, anlamlandırılmasını ve sentezlenmesini içermektedir (Özkan, 2019). Doküman incelemesi kişisel dokümanlarda kullanıldığı gibi kamu ve arşiv dokümanlarında da kullanılabilir. Kamu dokümanları, kurumların olay ya da süreçlerin göstergesi olarak düşünülebilir. Bu nedenle eğitimdeki değişimlerin ve süreçlerin ortaya konulması açısından değerli kaynaklar olduğu söylenebilir. Rehberlik ve denetim rehberleri de MEB Teftiş Kurulu Başkanlığının denetimde uygulama birliği ve standartlaşmayı sağlamak amacıyla kullandığı kamu 
belgeleri olarak doküman incelemesine uygun kaynaklar olarak görülmüş ve doküman incelemesinin aşamalarına göre analiz edilmiştir.

\section{Çalışma Dökümanı, Veri Toplanması ve Analizi}

Milli Eğitim Bakanlığı Teftiş Kurulu Başkanlığı tarafından, çeşitli kurumların teftişine yönelik olarak maarif müfettişlerinin görevlerini uygularken esas alacakları yönergeleri içeren 16 adet denetim rehberi hazırlanmıştır. Araştırmada çalışma dökümanları olarak kullanılan Rehberlik ve Araştırma Merkezleri Rehberlik ve Denetim Rehberi, Rehberlik ve Psikolojik Danışma Hizmetleri Yönetmeliği, Özel Eğitim Hizmetleri Yönetmeliği, Milli Eğitim Bakanlığı Teftiş Kurulu Yönetmeliği, 5510 sayllı Sosyal Sigortalar ve Genel Sağlık Sigortası Kanunu belgelerine MEB Teftiş Kurulu Başkanlığı ve Resmi Gazete web sayfalarından erişilmiştir. Yasal belgelere ve alanyazın belgelerine ulaşmak için çevrim içi ortamdan ve kitaplardan yararlanılmıştır. Rehbere, MEB Teftiş Kurulu Başkanlığı'nın internet sitesinin (tkb.meb.gov.tr) "Yayımlarımız" sayfasından 24.04.2020 tarihinde ulaşılmıştır. Yasal belgelere ve alanyazına çevirim içi ortam ile araştırmacının sanal ve gerçek kütüphanesinde bulunan kaynaklardan ulaşılmıştır. Bu çalışmanın sınırlığını, denetim rehberinin incelemesinin ulaşılan belgeler eşliğinde yapılması oluşturmaktadır. Ulaşılan belgelerin orjinalliği uzman görüşleri ve çevrim içi olanaklar ile teyit edilmiştir. Denetim rehberi ve rehberde yer verilen tüm mevzuat detaylı olarak incelenerek dökümanlar analiz edilmiştir.

Döküman incelemesi sonucunda ulaşılan veriler içerik analizi ile incelenmiştir. İçerik analizi, bir dizi işlem sonucu, dökümanın içeriğinden ulaşılan geçerli yorumların ortaya konulmasıdır ve bu yorumlar mesajın göndereni, mesajın kendisi ve mesajın alıcısı hakkındadır (Weber, 1990). Çalışmada, veriler ilişkilendirilerek kodlara, kategorilere ve temalara ulaşılış̧ır. Bu süreçte çelişkiye düşülen durumlarda kaynaklara, meslektaş teyidine ve uzman görüşüne başvurulmuştur. Tablo 1'de; Rehberlik ve Araştırma Merkezleri Rehberlik ve Denetim Rehberinin yasal belgeler ile alanyazın temelindeki analizi sonucu belirlenen kod, kategori ve temalara ilişkin örnek ifadeler görülmektedir.

Tablo1'de, denetim rehberinin yasal belgeler ve alanyazın ile olan ilişkisi temalar olarak biçimlenirken, yasal belgeler ve alanyazın ile ilişkisinde tutarlılk ve tutarsızlık kategoriler olarak tespit edilmiş ve son olarak ayrı ayrı olmak üzere "Yasal dayanağa göre uygunluk", "Yasal dayanağa göre güncel olmama", "Yasal dayanak belirsizliği", "ilgili yasal dayanaklara eksik gönderme", "Yasal dayanağa internet ortamında ulaşamama", "Yasal dayanağa göre eksik ifade edilme", "Yasal dayanağın hatalı ifade edilmesi", "Yasal dayanağa göre fazla ifade edilme", "Uygunluk", "içerik eksikliği", "Atıfsılık", "Kavram tutarsızlığı" ve "Aykırılı" ise kodlar olarak belirlenmiştir.

\section{Geçerlik ve Güvenirlik}

Nitel araştırmalarda geçerlik ve güvenirliğin sağlanabilmesi için bazı önlemler alınmaktadır. Bunun için uzman görüşü ve meslektaş teyidi gibi çeşitli stratejiler kullanılmaktadır. Meslektaş teyidi elde edilen verilerin karşılaştırılarak uyuşumun ortaya konmasına yönelikken uzman incelemesi, araştırma sürecine eleştirel gözle bakan ve araştırmacıya geribildirimde bulunan uzman görüşünü ifade etmektedir (Creswell, 2003; Yıldırım ve Şimşek, 2018). Araştırmanın geçerliğinin sağlanması için öncelikle meslektaş teyidine gidilmiştir. Bu amaçla MEB Teftiş Kurulu Başkanlığı'nın farklı kurumlara yönelik rehberlik ve denetim rehberlerini inceleyen araştırmacılar düzenli aralıklarla bir araya gelmiştir. Internet ortamında her hafta belirlenen gün ve saatte canlı toplantı araçları üzerinden toplantılar düzenlenmiş ve tekrar izlenebilmesi için bu toplantılar kaydedilmiştir. Toplantılarda öncelikle rehberlerin hangi yönlerden incelenebileceğine ilişkin tartışmalar gerçekleştirilmiştir. Ardından araştırmacılar inceleyecekleri rehberlere yönelik içerik analizi yaparak temaları ve alt temaları oluşturmuştur. Oluşturulan temalar ve alt temalar karşılaştıılarak benzer ve farklı yönler üzerinde durulmuştur. Anlaşmazlığa düşülen noktalar tartışılmış ve fikir birliğine ulaşııncaya dek toplantılar sürdürülmüştür. Bu toplantılarda uzman görüşü alınması amacıyla denetim alanında yayınları olan alanında yetkin bir akademisyen ile bir maarif müfettişi de yer almıştır. Bu uzmanlar toplantı sürecinde geribildirimlerde bulunmuşlardır. 
Geçerlik ve güvenirliğin sağlanması için değerlendirilen rehberlerin görüş birliğine dayalı olarak analiz edilmesine ve ayrıntılı raporlaştırılmasına dikkat edilmiştir. Ayrıca dış güvenirliği artırmak amacıyla talep edilmesi durumunda paylaşılması ya da başka bir araştırmada karşılaştırma yapılabilmesi için araştırmanın ham verileri saklanmıştır.

Tablo 1. Rehberlik ve Araştırma Merkezleri Rehberlik ve Denetim Rehberinin yasal belgeler ile alanyazın temelindeki analizi sonucu belirlenen kod, kategori ve temalara ilişkin örnek ifadeler

\begin{tabular}{|c|c|c|c|}
\hline Temalar & Kategoriler & Kodlar & iffadeler \\
\hline \multirow{4}{*}{$\begin{array}{l}\text { Denetim } \\
\text { Rehberini } \\
\text { n Yasal } \\
\text { Belgelerl } \\
\text { e ilişkisi }\end{array}$} & \multirow[t]{2}{*}{$\begin{array}{c}\text { Denetim } \\
\text { Rehberinin } \\
\text { Yasal } \\
\text { Belgelerle } \\
\text { Tutarlılığı }\end{array}$} & 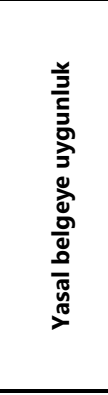 & $\begin{array}{l}\text { Rehberde; "5510 sayılı Sosyal Sigortalar ve Genel Sağlık Sigortası Kanunu'nun } 59 . \\
\text { maddesindeki, "Bu kanunun uygulanmasına ilişkin işlemlerin denetimi, Kurumun denetim ve } \\
\text { kontrol ile görevlendirilmiş memurları eliyle yürütülür... Kamu idarelerinin denetim ve kontrolle } \\
\text { görevlendirilmiş memurları, kendi mevzuatı gereğince işyerlerinde yapacakları soruşturma, } \\
\text { denetim ve incelemeler sırasında, çalıştırılanların sigortalı olup olmadığını da tespit ederek, } \\
\text { sigortasız çalıştırılanları Kuruma bildirmek zorundadır." hükümleri denetimin dayanağını teşkil } \\
\text { etmektedir." } \\
\text { Yasal Belgedeki Karşılığı; "Bu kanunun uygulanmasına ilişkin işlemlerin denetimi, Kurumun } \\
\text { denetim ve kontrol ile görevlendirilmiş memurları eliyle yürütülür... Kamu idarelerinin denetim } \\
\text { ve kontrolle görevlendirilmiş memurları, kendi mevzuatı gereğince işyerlerinde yapacakları } \\
\text { soruşturma, denetim ve incelemeler sırasında, çalıştırılanların sigortalı olup olmadığını da tespit } \\
\text { ederek, sigortasız çalıştırılanları Kuruma bildirmek zorundadır. }\end{array}$ \\
\hline & & \multicolumn{2}{|r|}{$\begin{array}{l}\text { Rehberde belirtilen maddenin, gönderme yapılan yasal belgedeki ifadeyle örtüşmesinden dolayı "yasal } \\
\text { belgeye uygunluk kodu" tercih edilmiştir. }\end{array}$} \\
\hline & \multirow[t]{2}{*}{$\begin{array}{c}\text { Denetim } \\
\text { Rehberinin } \\
\text { Yasal } \\
\text { Belgelerle } \\
\text { Tutarsızlığı }\end{array}$} & 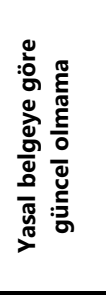 & $\begin{array}{l}\text { Rehberde; "Verilecek hizmetin niteliğine göre çeşitli psikolojik ölçme araçlarının bilimsel } \\
\text { standartlarına göre uygulanması (Milli Eğitim Bakanlığı Rehberlik ve Psikolojik Danışma } \\
\text { Hizmetleri Yönetmeliği Md. 30/d)." } \\
\text { Yasal Belgedeki Karşı̆ı̆ı; } \\
\text { " MADDE } 18 \text { - (1) Eğitim kurumu müdürü rehberlik ve psikolojik danışma hizmetlerine ilişkin } \\
\text { aşağıdaki görevleri yapar: a) Rehberlik ve psikolojik danışma hizmetlerinin yürütülmesinden } \\
\text { birinci derecede sorumludur. b) Rehberlik ve psikolojik danışma hizmetlerinin etkin şekilde } \\
\text { yürütülebilmesi için hizmetin gerektirdiği fiziksel şartları ve uygun çalışma ortamını hazırlar, } \\
\text { kullanılacak araçgereci sağlar." }\end{array}$ \\
\hline & & \multicolumn{2}{|r|}{$\begin{array}{l}\text { Rehberde belirtilen maddenin, gönderme yapılan yasal belgenin güncel halinde bulunamaması ve bu } \\
\text { maddenin yürürlükten kaldırılması nedeniyle "yasal belgeye göre güncel olmaması kodu" tercih edilmiştir. }\end{array}$} \\
\hline \multirow{4}{*}{$\begin{array}{l}\text { Denetim } \\
\text { Rehberini } \\
\text { n Alan } \\
\text { Yazınla } \\
\text { ilişkisi }\end{array}$} & \multirow[t]{2}{*}{$\begin{array}{l}\text { Denetim } \\
\text { Rehberinin } \\
\text { Alanyazınla } \\
\text { Tutarlılığı }\end{array}$} & 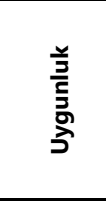 & $\begin{array}{l}\text { Rehberde; "Özel eğitim hizmetleriyle ilgili bilimsel gelişmelerin izlenmesi, bu gelişmelerden } \\
\text { uygulamalarda yararlanılması (Milli Eğitim Bakanlığı Rehberlik ve Psikolojik Danışma } \\
\text { Hizmetleri Yönetmeliği Md. 32/j)" } \\
\text { Alanyazındaki Karşılığı; Araştırmalara göre, özel eğitim alanının doğası gereği geliştirilen ve } \\
\text { kullanılan farklı yöntemlerin araştırmacıların en çok ilgi duyduğu konulardır (Yıldız, Melekoğlu, } \\
\text { \& Paftalı, 2016) }\end{array}$ \\
\hline & & \multicolumn{2}{|c|}{$\begin{array}{l}\text { Rehberde belirtilen maddenin, alanyazındaki ifadeyle örtüşmesinden dolayı "uygunluk kodu" tercih } \\
\text { edilmiştir. }\end{array}$} \\
\hline & \multirow[t]{2}{*}{$\begin{array}{c}\text { Denetim } \\
\text { Rehberinin } \\
\text { Alanyazınla } \\
\text { Tutarsızlığı }\end{array}$} & 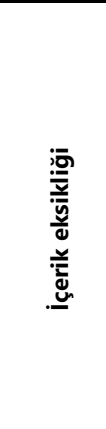 & $\begin{array}{l}\text { Rehberde; "bireysel ve kurumsal farklılılar ile çevresel faktörleri dikkate almak, yol gösterici ve } \\
\text { önleyici rehberliği öne çıkarmak, düzeltmeyi, iyileştirmeyi ve geliştirmeyi esas almak, iyi } \\
\text { uygulama örneklerini yaygınlaştırmak, usulsüzlük ve yolsuzlukları önleme yönelimli olmak, } \\
\text { açıklık, şeffaflık, eşitlik, demokratiklik, bağımsızlık, bütünlük, güvenilirlik ve tarafsızlığı esas } \\
\text { almak, işbirliği ve katıımı öngörmek, başarıyı öne çıkarmak, özendirmek, teşvik etmek ve } \\
\text { ödüllendirmek, personelin mesleki yeterliğini geliştirmek, objektif olmak, gelecek yönelimli } \\
\text { olmak, etkililik, ekonomiklik ve verimlilik esaslarını dikkate almak, milli birlik ve } \\
\text { bütünlüg̈ümüzün temel unsurlarından biri olan Türkçenin doğru kullanılması hususunda gerekli } \\
\text { duyarlı̆ı̆ı göstermek, kurumlarda rehberlik ve denetim faaliyetlerini birlikte yürütmek" } \\
\text { Alanyazındaki Karşığı; Denetim görevini yerine getirecek olan yöneticilerin davranışlarında } \\
\text { etik değerleri (eşitlik, saygı, korku yaratmama, inceleme-soruşturma ve rehberlik rollerinin } \\
\text { çatışmaması vb.) oluşturabilmek için, mesleki yeterliliklerinin buna uygun şekilde sağlanması } \\
\text { gerekmektedir (Aydın, 2006). }\end{array}$ \\
\hline & & edilmiştir & ayı "ic \\
\hline
\end{tabular}

Birlikte hareket edilerek şekilenen rehberlerle ilgili çalışmaların bazıları yayımlanmıştır (Toprakçı ve Bakır 2020; Tonbul ve Ata 2020; Özdemir ve Altuntaş 2020; Akçay Güngör 2020; Kahraman 2020; Tonbul ve Keleş 2020; Ölmez ve Algam 2020; Toprakçı ve Özerten 2020). Bu çalışma hakem süreci ve yazım ile ilgili iş ve işlemlerin uzamasından dolayı sonra yayımlandığından onlara vurgu yapmak gereği duyulmuştur. 


\section{BULGULAR VE YORUM}

Bu bölümde Rehberlik ve Araştırma Merkezleri Rehberlik ve Denetim Rehberi yasal belgeler ile alanyazın temelinde analiz edilmesi sonucu ortaya çıkan temaların ve kodların dağılımına, bulguları destekleyen alıntılara ve bu bulguların yorumlanmasına yer verilmiştir.

\section{Denetim Rehberinin Yasal Belgelerle İlişkisi}

Aşağıda yer alan Tablo 2'de denetim rehberinin yasal belgelerle ilişkisi teması altında "Denetim rehberinin yasal belgelerle tutarlıı̆ı" ve "Denetim rehberinin yasal belgelerle tutarsızlığı" kategorileri ve kodlarının dağılımları gösterilmiş̧tir.

Tablo 2. Denetim rehberinin yasal belgelerle ilişkisi teması atında ortaya çıkan kategori ve kodların dağılımı

\begin{tabular}{|c|c|c|c|}
\hline Tema & Kategoriler & Kodlar & $\mathbf{F}$ \\
\hline \multirow{8}{*}{ 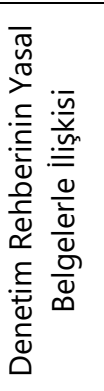 } & \multirow{4}{*}{$\begin{array}{l}\text { 1. Denetim Rehberinin Yasal } \\
\text { Belgelerle Tutarlılığı }\end{array}$} & Yasal dayanağa göre uygunluk & 25 \\
\hline & & Yasal dayanağa göre güncel olmama & 48 \\
\hline & & Yasal dayanak belirsizliği & 32 \\
\hline & & Yasal dayanağa internet ortamında & 11 \\
\hline & \multirow{4}{*}{$\begin{array}{l}\text { 2. Denetim Rehberinin Yasal } \\
\text { Belgelerle Tutarsızlığı }\end{array}$} & İlgili Yasal dayanaklara eksik gönderme & 9 \\
\hline & & Yasal dayanağa göre eksik ifade edilme & 4 \\
\hline & & Yasal dayanağın hatalı ifade edilmesi & 2 \\
\hline & & Yasal dayanağa göre fazla ifade edilme & 2 \\
\hline & & Toplam & 108 \\
\hline
\end{tabular}

Tablo 2 incelendiğinde "Denetim rehberinin yasal belgelerle tutarlıı̆ı" $(n=25)$ ve "Denetim rehberinin yasal belgelerle tutarsızlığı" olmak üzere iki temanın ön plana çıktığı görülmektedir. Ayrıca, Tablo 2'de de belirtildiği gibi, "Denetim rehberinin yasal belgelerle tutarsızlığı" $(n=108)$ kategorisi altında "Yasal dayanağa göre güncel olmama", "Yasal dayanak belirsizliği", "ilgili yasal dayanaklara eksik gönderme", "Yasal dayanağa internet ortamında ulaşamama", "Yasal dayanağa göre eksik ifade edilme", "Yasal dayanağın hatalı ifade edilmesi" ve "Yasal dayanağa göre fazla ifade edilme" kodları tespit edilmiştir.

\subsection{Denetim Rehberinin Yasal Belgelerle Tutarlıığı}

"Denetim rehberinin yasal belgelerle tutarlıı̆ı $(n=25)$ " kategorisi altında "Yasal dayanağa uygunluk" olarak bir tane kod tespit edilmiştir. "Denetim rehberinin yasal belgelerle tutarlıı̆ının" "Yasal dayanağa uygunluk" kodu, rehberdeki kısım ile yasal belgeye ilişkin gönderme örtüşüyorsa veya ikisi birbiriyle doğru şekilde ilişkilendirilmişse tercih edilmiştir. Örnek olarak, rehberin "Amaç, Kapsam ve Dayanak" bölümünde yer alan; "5510 sayılı Sosyal Sigortalar ve Genel Sağlık Sigortası Kanunu'nun 59. maddesindeki, "Bu kanunun uygulanmasına ilişkin işlemlerin denetimi, Kurumun denetim ve kontrol ile görevlendirilmiş memurları eliyle yürütülür... Kamu idarelerinin denetim ve kontrolle görevlendirilmiş memurları, kendi mevzuatı gereğince işyerlerinde yapacakları soruşturma, denetim ve incelemeler sırasında, çalıştırlanların sigortalı olup olmadığını da tespit ederek, sigortasız çalıştırılanları Kuruma bildirmek zorundadır." hükümleri denetimin dayanağını teşkil etmektedir." ifadesinde atıf yapılmış olan yasal belgede de aynı ifadeler bulunmaktadır.

Görüldüğü üzere, rehberdeki kısım ile gönderme yapılan yasal belgenin ilgili maddesi doğru bir şekilde ilişkilendirildiğinden bu ifade "Denetim rehberinin yasal belgelerle tutarlı̆̆ı" kategorisinin "Yasal dayanağa uygunluk $(n=25)$ " kodu altında incelenmiştir. Bu koda ilişkin ifadelerin az sayıda çıkmış olması, denetim rehberinin yasal belgelerle ilişkisinin tutarlılık temelinde olumsuz olduğunu göstermektedir. Bu durum rehberin hazırlandığı tarihte gönderme yapılan yasal belgelerin güncelliğini korumaması ile açıklanabilir. Buna göre rehberin niteliği ile ilgili olarak da bir eksiklikten söz edilebilir. 


\subsection{Denetim Rehberinin Yasal Belgelerle Tutarsızlığı}

Denetim rehberinin yasal belgelerle tutarsızlığ $(n=108)$ kategorisinin kodları incelendiğinde Yasal dayanağa göre güncel olmama $(n=48)$ kodu rehberdeki ifadenin ya da bu ifadenin yanında yer alan yasal belgenin güncel olmadığı ya da yürürlükten kaldırıldığı durumda tercih edilmiştir. Rehberdeki "Eğitim-Öğretim Faaliyetlerini Destekleyici Hizmetler" bölümünde yer verilen "Verilecek hizmetin niteliğine göre çeşitli psikolojik ölçme araçlarının bilimsel standartlarına göre uygulanması (Milli Eğitim Bakanlığı Rehberlik ve Psikolojik Danışma Hizmetleri Yönetmeliği Md. 30/d)" ifadesi bu koda örnek verilebilir. Denetim rehberinde yapılmış olan bu alıntı incelendiğinde, 17 Nisan 2001 tarihli Rehberlik ve Psikolojik Danışma Hizmetleri Yönetmeliği; ilk olarak 10 Kasım 2017 tarih ve 30236 sayılı Resmi Gazetede yayınlanan Millî Eğitim Bakanlığı Rehberlik Hizmetleri Yönetmeliği ile son olarak ise 14 Ağustos 2020 tarih ve 31213 sayılı Resmi Gazetede yayınlanan Milli Eğitim Bakanlığı Rehberlik ve Psikolojik Danışma Hizmetleri Yönetmeliği ile iki kez güncellendiği ancak rehberin aynı kaldığı görülmektedir. Bir başka örnek ise rehberde atıf yapılan Özel Eğitim Hizmetleri Yönetmeliğidir. Özel Eğitim Hizmetleri Yönetmeliği; ilk olarak 7 Temmuz 2018 tarihli ve 30471 sayılı Resmi Gazete'de yayınlanmış, daha sonra ise 11 Haziran 2020 tarihli ve 31152 sayılı Resmi Gazetede yayınlanarak yeniden güncellenmiştir ancak rehber yine aynı kalmıştır. Bu kod, rehberin güncel olmadığını göstererek güncellenmesi gerektiğini ortaya koymaktadır.

Yasal dayanak belirsizliği $(n=32)$ kodu ilgili konuya ilişkin yasal belgeye açıkça gönderme yapılmadığı durumlar tespit edildiğinde kullanılmıştır. "Yasal dayanak belirsizliği $(n=32)$ " koduna; rehberin Yönetim Faaliyetleri bölümünün "Öğrenci/birey işleri" alt başlığında yer alan "öğrenci/bireylerin kabul işlemleri, öğrenci/bireylerin yönlendirme işlemleri, öğrenci/bireylere yönelik verilerin sisteme zamanında işlenmesi" ifadesi örnek gösterilebilir. Örnekteki ilgili ifadeye ilişkin hiçbir yasal belgeye gönderme yapılmamıştır. Bu ifadelere yönelik "Milli Eğitim Bakanlığı Rehberlik ve Psikolojik Danışma Hizmetleri Yönetmeliği, 2020"nin Rehber öğretmen/psikolojik danışmanın görevleri alt başlığındaki 21. madde $(b, c, c ̧, a)$ ve sınıf öğretmeninin görevleri alt başlı̆ındaki 23. madde $(b, c, e, g, g, h, h, i)$ gibi bazı maddeler yasal dayanak olarak verilebilirdi.

Yasal dayanağa internet ortamında ulaşamama $(n=11)$ kodu rehberin içeriğinde gönderme yapılan yasal belgeye internet ortamında ulaşılamadıysa kullanılmıştır. Söz konusu koda örnek olarak, rehberin "Eğitim-öğretim faaliyetlerini destekleyici hizmetler" bölümünün "uygulama" alt başlığındaki 7. maddeye dayanak olarak verilmiş olan; "5793 Sayılı Bazı Kanun ve Kanun Hükmünde Kararnamelerde Değiş̧iklik Yapılmasına Dair Kanun; Özel Eğitim, Rehberlik ve Danışma Hizmetleri Genel Müdürlüğünün 09.10.2009 tarih ve 4448 sayılı ve Eğitsel Değerlendirme, Tanılama ve Özel Eğitim Uygulamaları konulu yazısı" internet ortamında ulaşılamamış bir belge olarak örnek gösterilebilir.

ilgili yasal dayanaklara eksik gönderme $(n=9)$ kodu; rehberde gönderme yapılan ilgili belgede başka maddelere de atıf yapılması gerekiyorsa, araştırmalar esnasında gönderme yapılan yasal belgeler dışında başka destekleyici belgelere de ulaşıldıysa fakat bunlara rehberde değinilmediyse tercih edilmiştir. Bu koda ilişkin rehberin "Eğitim-öğretim faaliyetlerini destekleyici hizmetler" bölümünün "kurum-çevre ilişkileri" alt başlığında yer alan "Özel eğitim konusunda, ailelere yönelik çeşitli bilgilendirme ile rehberlik programı ve çalışmalarının yapılması" maddesine ilişkin yasal dayanak olarak "Milli Eğitim Bakanlığı Rehberlik ve Psikolojik Danışma Hizmetleri Yönetmeliği, 2016"nın 32. maddesine yer verilmiştir. Ailelere yönelik çeşitli bilgilendirme ile rehberlik programı ve çalışmalarının yapılması hususunda farklı bir yasal belge olarak "MEB, Özel Eğitim Hizmetleri Yönetmeliği, 2020"'nin "aile eğitimi hizmetleri" bölümündeki 18. madde dayanak gösterilebilir. İlgili madde; "Aile eğitimi, her tür ve kademedeki özel eğitim ihtiyacı olan ögrencilerin eğitimine katkı sağlamak amacıla aileye verilecek her türlü rehberlik ve eğitim hizmetlerini içerir. Bu hizmetler Bakanlıkça hazırlanan aile eğitimi programı doğrultusunda okul ve kurumlarda yürütülür" şeklindedir ve rehberdeki madde ile ilişkilidir.

Yasal dayanağa göre eksik ifade edilme $(n=4) "$ kodu, verilmiş olan yasal dayanağın içeriğine ve maddelerine ilişkin kapsamın denetim rehberinde eksik verilmiş olduğu durumları 
ifade etmektedir. İlgili koda ilişkin örnek olarak rehberdeki; "Yönetim Faaliyetleri" bölümündeki "örgütleme" alt başlığında yer verilen "Özel eğitim değerlendirme kurulunun oluşturulması ve görevlerini yapması Özel Eğitim Hizmetleri Yönetmeliği Md. 19-22" ifadesindeki ilgili maddeler 2009 yılındaki özel eğitim değerlendirme kurulunun oluşturulması ve görevlerini yapması ifadelerinden farklı ve ayrıca özel eğitim değerlendirme kurulunun çalıșma usul ve esasları ifadesini içermektedir ancak bu ifade, yasal dayanağına rağmen denetim rehberinde geçmemektedir.

Yasal dayanağın hatalı ifade edilmesi $(n=3)$ kodu; gönderme yapılan yasal belgede madde numarası doğru değilse ya da gönderme yapılan yasal belgenin kendisi doğru ifade edilmemişse tercih edilmiştir. "Eğitim-öğretim faaliyetlerini destekleyici hizmetler" bölümünün "uygulama" alt başlığında yer verilmiş olan "Eğitim ortamlarında şiddetin önlenmesi ve azaltılması, psiko-sosyal müdahale hizmetlerinin yürütülmesi" ifadesine yönelik verilen yasal dayanak "Özel Eğitim, Rehberlik ve Danışma Hizmetleri Genel Müdürlüğünün 2009/09 sayılı genelgesi" dir. Bu ifadeye ilişkin genelge 2009/06 sayılı genelgedir ve rehberde yasal dayanağın madde sayısı yanlış ifade edilmiştir.

Yasal dayanağa göre fazla ifade edilme $(n=2)$ kodu, rehberde fazla veya detaylı ifade edilmiş maddeler varsa kullanılmıştır. Rehberde, "Amaç, kapsam, dayanak ve tanımlar" bölümünde yer alan, 652 sayılı Milli Eğitim Bakanlığının Teşkilat ve Görevleri Hakkında Kanun Hükmünde Kararnamenin 17. maddesinin birinci fıkrasının ç bendinde; "Bakanlık teşkilatı ile Bakanlığın denetimi altındaki her türlü kuruluşun faaliyet ve işlemlerine ilişkin olarak, usûlsüzlükleri önleyici, eğitici ve rehberlik yaklaşımını ön plana çıkaran bir anlayışla, Bakanlığın görev ve yetkileri çerçevesinde denetim, inceleme ve soruşturmalar yapmak." ifadesi rehberde; "Bakanlık teşkilatı ve personeli ile Bakanlığın denetimi altındaki her türlü kuruluşun faaliyet ve işlemlerine ilişkin olarak, usülsüzlükleri önleyici, eğitici ve rehberlik yaklaşımını ön plana çıkaran bir anlayışla, Bakanlığın görev ve yetkileri çerçevesinde denetim, inceleme ve soruşturma iş ve işlemlerini Maarif Müfettişleri aracılığıyla yapmak" olarak geçmektedir. Buna göre rehberde, "personel" ve "iş ve işlemlerini maarif müfettişleri aracılığıyla yapmak" ifadelerine, yasal belgede olmamasına rağmen yer verilmiş olduğu görülmektedir.

\section{Denetim Rehberinin Alanyazınla iliş̧kisi}

Aşağıda yer alan Tablo 3'te Denetim rehberinin alanyazınla ilişkisi teması altında Denetim Rehberinin alanyazınla tutarlıı̆ı ve Denetim rehberinin alanyazınla tutarsızlığı kategorileri ile kodları verilmiştir. Bu bölümde Denetim Rehberi ya da Rehberlik ve Araştırma Merkezleri ile ilgili doğrudan bir alanyazın çalışmasının yokluğu nedeniyle dolaylı çalışmalar incelendiği için sayısallaştırmaya gidilmemiştir.

\subsection{Denetim Rehberinin Alanyazınla Tutarlıığı}

Yapılan incelemelere yönelik olarak rehberin alanyazınla genel olarak tutarlı olduğu görülmüştür. Buna yönelik olarak, rehberin Eğitim-Öğretim Faaliyetlerini Destekleyici Hizmetler bölümünün Özel Eğitim Hizmetleri alt başlığında yer alan "Özel eğitim hizmetleriyle ilgili bilimsel gelişmelerin izlenmesi, bu gelişmelerden uygulamalarda yararlanılması (Milli Eğitim Bakanlığı Rehberlik ve Psikolojik Danışma Hizmetleri Yönetmeliği Md. 32/j)" ifadesi Denetim Rehberinin alanyazınla tutarlıı̆ı temasının "Uygunluk" koduna bir örnek olarak verilebilir. Araştırmalara göre, özel eğitim alanının doğası gereği geliştirilen ve kullanılan farklı yöntemlerin uygulamaya geçirilme süreçlerinin incelenmesi araştırmacıların üzerinde çalışığı konulardan birisidir (Yıldız, Melekoğlu, \& Paftalı, 2016). Özel eğitim hizmetleriyle ilgili bilimsel gelişmelerin izlenmesi ve bu gelişmelerden uygulamalarda yararlanılması, bu alanın bilimsel bir nitelikte olduğunu, bu nitelik ile birlikte gelişime ve ilerlemeye açık olduğunu da göstermektedir.

\subsection{Denetim Rehberinin Alanyazınla Tutarsızlığı}

Denetim Rehberinin incelenmesi sonucu alanyazınla tutarsız olan noktalar tespit edilmiştir. Buna göre Tablo 3'te analiz sonucu ortaya çıkan tema, kategori ve kodlar verilmiştir. 
Tablo 3. Denetim Rehberinin alanyazınla ilişkisi teması altında ortaya çıkan kategori ve kodların dağılımı

\begin{tabular}{|c|c|c|}
\hline Tema & Kategoriler & Kodlar \\
\hline \multirow[b]{2}{*}{ 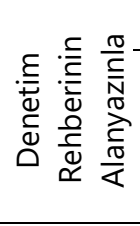 } & 1. Denetim Rehberinin Alanyazınla Tutarlılığı & Uygunluk \\
\hline & 2. Denetim Rehberinin Alanyazınla Tutarsızlığı & $\begin{array}{l}\text { İçerik Eksikliği } \\
\text { Atıfsızlık } \\
\text { Kavram Tutarsızlığı } \\
\text { Aykırılık }\end{array}$ \\
\hline
\end{tabular}

Tablo 3'te görüldüğü gibi, Denetim rehberinin alanyazınla ilişkisi temasının Denetim rehberinin alanyazınla tutarsızlığı kategorisine ait "içerik eksikliği", "Atıfsızlık", "Kavram tutarsızlığı" ve "Aykırılık" olmak üzere dört kod tespit edilmiştir. "Denetim rehberinin alanyazınla tutarsızlığı" kategorisinin "iç̧erik eksikliği" kodu alanyazında olan fakat rehberde olmayan kavramlar tespit edildiğinde tercih edilmiştir. Bu bağlamda, rehberin Rehberlik ve Denetim ilkeleri bölümü örnek gösterilebilir. Bu bölümde; "bireysel ve kurumsal farklılıklar ile çevresel faktörleri dikkate almak, yol gösterici ve önleyici rehberliği öne çıkarmak, düzeltmeyi, iyileştirmeyi ve geliştirmeyi esas almak, iyi uygulama örneklerini yaygınlaştırmak, usulsüzlük ve yolsuzlukları önleme yönelimli olmak, açıklık, şeffaflık, eşitlik, demokratiklik, bağımsızlık, bütünlük, güvenilirlik ve tarafsızlığı esas almak, işbirliği ve katılımı öngörmek, başarıyı öne çıkarmak, özendirmek, teşvik etmek ve ödüllendirmek, personelin mesleki yeterliğini geliştirmek, objektif olmak, gelecek yönelimli olmak, etkililik, ekonomiklik ve verimlilik esaslarını dikkate almak, milli birlik ve bütünlüğümüzün temel unsurlarından biri olan Türkçenin doğru kullanılması hususunda gerekli duyarlıığı göstermek, kurumlarda rehberlik ve denetim faaliyetlerini birlikte yürütmek" ifadeleri, rehberlik ve denetim yapılırken göz önünde bulundurulacak ilkeleri kapsamaktadır. Burada, rehberlik ve denetim yapılırken göz önünde bulundurulması gereken ve alanyazında bulunan "Etik" kavramı ilkesel olarak eksiktir. Rehberlik ve denetimde etik ilkeler değerleri kapsamaktadır. Etik ilkelere dayanan değerler; saygıyı, gizliliği, adaleti, eşitliği, objektifliği, gelişmeyi ve standartları oluşturmaktadır. Denetim görevini yerine getirecek olan yöneticilerin davranışlarında etik değerleri; eşitlik, saygı, korku yaratmama, inceleme-soruşturma ve rehberlik rollerinin çatışmaması vb. oluşturabilmek için, mesleki yeterliliklerinin buna uygun şekilde sağlanması gerekmektedir (Aydın, 2006). Rehberde, rehberlik ve denetim ilkeleri bölümündeki bu eksikliğin nedeni, rehberi hazırlamakla yükümlü olan kişilerin yahut bu kişilerin içlerinde bulundukları sistemin felsefi temellere önem vermemesi, bilimsel yöntemle hareket etmemesi, eğitim sisteminde ve denetim faaliyetlerinde etik kavramının göz ardı edilmesi olabilir. Herhangi bir kurumun başında yönetim görevini yürüten yöneticiler, o görevi yapabilmeleri için gerekli yeterliklere sahip olmalılardır (Arslan \& Sevinç, 2020). Yöneticilere verilen eğitimlerde, bilimsel araştırmalarda eğitimde değerler ve etik ile ilgili derslerin sayısı artıııırmasının olumlu olacağı düşünülmektedir (Kadı, Beytekin \& Arslan, 2016). Alanyazında yapılan çalışmalara göre, eğitim müfettişlerinin, işlevsel bir rehberlik ve denetim yapmakta yetersiz kaldığı ve gerekli bilgi ve becerileri kazanmak için eğitimler almaları gerektiği belirtilmektedir (Ekinci \& Karakuş, 2011).

Atıfsızlık kodu, alanyazınla tutarlı ya da tutarsız olarak, rehberin konusu ile ilgili yapılmış bilimsel çalışmalara gönderme yapmama durumunu ifade etmektedir. Rehberin İleme ve Değerlendirme bölümünde yer verilen "Rehberlik ve denetimi yapılan kurumun bir önceki denetim raporunda yer alan tespit ve önerilerin uygulanmasına ilişkin olarak, denetlenen birimce hazırlanan "Gelişim Planı" çerçevesinde yürütülen çalışmalar ve düzeyi değerlendirilecek, gelişim planı ile ilgili varsa sorunlar ve çözümler önerilerine yer verilecektir." ifadeleri bu koda örnek olarak gösterilebilir. izleme ve Değerlendirme bölümünde; araştırmacıların izleme ve değerlendirme yaparken nelere dikkat etmesi gerektiğine, gelişim planları ile ilgili tespit edilen sorunlara ve çözüm önerilerine yer veren çalışmalara, farklı ülkelerdeki gelişim planı örneklerine dair alanyazındaki incelemelere atıf yapılabilir. Rehberin incelenmesi sonucu ortaya çıkan bu kod sayesinde, rehber hazırlanırken bilimsel bilgi üretme amacının yanısıra yalnızca mevzuata bağı kalınmış olduğu söylenebilir. Etkili bir denetim için bilginin temel alınması önem taşımaktadır 
(Hoy ve Miskel, 1978). Bu bağlamda eğitbilimcilerin pratiğin teorilerini hazırladıklarında ve bu birikim yasal belgelere yansıtıldığında eğitim bilimliliğinden söz edilebilir (Toprakçı, 2008; Toprakçı, Dağdeviren, Oflaz ve Türe 2010).

Kavram tutarsızlığı kodu, rehberdeki kavramların kullanımının; kavramın alanyazındaki biçimi ile tutarsız olduğu ya da farklı kavramların birbirlerini kapsaması durumunu ifade etmektedir. Rehberde, "rehberlik" ve "denetim" kavramları ayrı ayrı kullanılmıştır. Alanyazındaki hali ile "denetim" kavramı; "rehberlik" kavramını içine almaktadır. Rehberin "Tanımlar" bölümünde; "Denetim: Genel olarak kamuda, özel ve tüzel kişiliği bulunan kurum ve kuruluşlarda yapılmakta olan işlerin; kaynak, imkan ve şartlar dikkate alınarak, yasal çerçeve ile belirlenen amaç, öngörülen temel ilke ve hedeflere uygunluğunu, doğruluğunu, düzenliliğini, verimliliğini, ekonomikliğini, etkinliğini; objektif, geçerli, güvenilir ölçütlere göre karşılaştırma yapabilme, ulusal standartlara ve planlanan esaslara göre durumunu ortaya koyma, giderilebilir eksiklikler için rehberlikte bulunma, değişim ve gelişim için misyon ve vizyon kazandırmaya ilişkin öneriler getirme sürecidir." ifadelerinde görüldüğü üzere, denetim kavramının içerisinde rehberlik kavramı da geçmektedir. Buradaki kavram tutarsızlığının, alanyazından atıf yapılarak veya bu rehberde hangi kavramın hangi şekilde, neye dayanarak kullanıldığına dair belirtmeler yapılarak giderilmesi gerekmektedir. Bu sonuca göre, rehberi hazırlamakla yükümlü olan görevlilerin, denetimin alanyazın temelinde eksik oldukları söylenebilir.

Aykırlık kodu, denetim rehberinde alanyazınla çelişen ve düzeltilmesi gereken bir durum olduğunu ifade etmektedir. Bu bağlamda, rehberin "Rehberlik ve Denetim ilkeleri" bölümü örnek gösterilebilir. Bu bölümde; "bireysel ve kurumsal farklılıklar ile çevresel faktörleri dikkate almak, yol gösterici ve önleyici rehberliği öne çıkarmak, düzeltmeyi, iyileştirmeyi ve geliştirmeyi esas almak, iyi uygulama örneklerini yaygınlaştırmak, usulsüzlük ve yolsuzlukları önleme yönelimli olmak, açıklık, şeffaflık, eşitlik, demokratiklik, bağımsızık, bütünlük, güvenilirlik ve tarafsızlığı esas almak, işbirliği ve katılımı öngörmek, başarıyı öne çıkarmak, özendirmek, teşvik etmek ve ödüllendirmek, personelin mesleki yeterliğini geliştirmek, objektif olmak, gelecek yönelimli olmak, etkililik, ekonomiklik ve verimlilik esaslarını dikkate almak, milli birlik ve bütünlüğümüzün temel unsurlarından biri olan Türkçenin doğru kullanılması hususunda gerekli duyarlıı̆ı göstermek, kurumlarda rehberlik ve denetim faaliyetlerini birlikte yürütmek" ifadeleri, rehberlik ve denetim yapılırken göz önünde bulundurulacak ilkeleri kapsamaktadır. Bu ifadelerde yer alan; "Milli birlik ve bütünlüğümüzün temel unsurlarından biri olan Türkçenin doğru kullanılması hususunda gerekli duyarlılığı göstermek" ifadesi, denetimin ve rehberliğin ilkelerinin incelendiği alanyazında bulunmamaktadır. Dolayısıyla, alanyazında bulunmayan bir ilkeye denetim rehberinde yer verilmesi, alanyazınla çelişen bir ifadeye neden olmaktadır. Milli birlik ve bütünlüğümüzün temel unsurlarından biri olan Türkçenin doğru kullanılması, eğitimde çok önemli bir yer teşkil etmekle ve her durumda korunması gerekmekle birlikte, denetim ve rehberliğin ilke ve esasları içerisinde alanyazında bulunmamaktadır. Bu ilkenin, iletişime ilişkin bir başlık altında kullanılması uygun görülmektedir.

\section{SONUÇ VE ÖNERILER}

Araştırmada, Rehberlik ve Araştırma Merkezleri Rehberlik ve Denetim Rehberi ile ilgili yasal belgeler ve alanyazın temelinde incelenmesi sonucunda denetim rehberi içerisinde yer alan maddelerin ilgili yönergelerle tutarlılığı ve tutarsızlığı tespit edilmeye çalışılımışır. Bu inceleme sonucunda, Rehberlik ve Araştırma Merkezleri Rehberlik ve Denetim Rehberinin yasal belgelerle tutarlıı̆̆ının tutarsızlığa göre çok düşük olduğu görülmektedir. Böyle bir rehber içerisindeki tutarsızlık, rehberden yararlanmak isteyen denetim sorumlusunun yanlış yönlendirilmesine, hatalı ya da eksik davranışlarda bulunmasına veya denetim ve rehber olma eyleminin yeterli bir şekilde yerine getirilememesi gibi sonuçlara neden olabilir. Bu sebeple rehberin tutarlılığının arttırılabilmesi için araştırmacılar ve uygulayıcılar çalışmalar yapabilirler ve rehberi tutarlı bir şekilde güncelleyebilirler. 
Rehberlik ve Araştırma Merkezleri Rehberlik ve Denetim Rehberinin yasal belgelerle tutarsızlığının çok yüksek olduğu görülmektedir. Denetim rehberi içerisindeki maddelerin atıf yapmış olduğu yasal belgelerin rehberden sonraki yıllarda değişmiş olduğu görülmektedir ve buna yönelik olarak rehberin güncellenmesi gerekmektedir. Rehber, yürürlükteki haliyle güncel değildir. Özel Eğitim Hizmetleri Yönetmeliği ve Milli Eğitim Bakanlığı Rehberlik Hizmetleri Yönetmeliği rehberden sonraki yıllarda güncellenmiş ve değişmiştir ancak rehberin bu yasal dayanaklara yaptığı atıflar değişmemiştir. Rehberdeki maddelere, güncellenen yasal belgelerde ulaşılamamıştır. Rehberlik ve Araştırma Merkezleri Rehberlik ve Denetim Rehberinin değişen ve güncellenen yasal belgelere yönelik olarak değişmesi gerekmektedir. Rehberlerin güncel kalması için, denetim rehberlerinden sorumlu olan araştırmacıların oluşturacağı bir veritabanı kurulabilir ve bu veritabanındaki bilgiler güncellendikçe, internet bağlantısı aracılığıyla veritabanından faydalanarak rehber güncellenebilir. Böyle bir veritabanı, yasal belgelere ulaşmayı ve belgeleri güncellemeyi kolaylaştıracaktır.

Rehberde yasal belgelere atıf yapılmadığı, yasal dayanak olmadığı ve yasal dayanağa eksik gönderme yapıldığı belirlenmiştir. Bu rehberde, ifadelerin yasal dayanaklarının doğru şekilde kullanılması denetim ve rehberlik faaliyetlerinin yasal zeminini oluşturmakta ve bu faaliyetleri meşru kılmaktadır. Ayrıca yasal dayanaklara gönderme yapılmış olması, herhangi bir belirsizlik, karışıklık ya da anlaşılamama durumunda belirtilen yasal dayanağa ulaşılarak ifadelerin teyidinin gerçekleştirilmesini sağlamaktadır. Yasal dayanaklara gönderme yapılması bu nedenler ile önemlidir. Rehberi hazırlama sürecinde kullanılacak yasal belgelerin incelenmesi için bir kurul oluşturulabilir.

Rehberde atıf yapılmış olan "5793 Sayılı Bazı Kanun ve Kanun Hükmünde Kararnamelerde Değişiklik Yapılmasına Dair Kanun; Özel Eğitim, Rehberlik ve Danışma Hizmetleri Genel Müdürlüğünün 09.10.2009 tarih ve 4448 sayılı ve Eğitsel Değerlendirme, Tanılama ve Özel Eğitim Uygulamaları konulu yazısı" belgesine internet ortamında ulaşılamamıştır. Rehberde atıf yapılmış olan belgelerin ulaşılabilir olması, bu rehberin amacına ulaşmasına yardımcı olmakta ve denetim sorumlularının görevlerini yerine getirirken rehberde yer alan belgelerden de faydalanmalarını sağlamaktadır. Bu nedenle rehberde kullanılan belgelerin güncelliği ve ulaşılabilirliği kontrol edilmelidir. Belgelerin ulaşılabilir olması için bir veritabanı düzenlenebilir. Araştırmacıların işini kolaylaştırmak ve tutarlı, bilimsel rehberler hazırlamak için farklı ülkelerin denetim konusundaki yasalarının takip edilmesi önerilebilir.

Rehberde yer alan "Bakanlık teşkilatı ile Bakanlığın denetimi altındaki her türlü kuruluşun faaliyet ve işlemlerine ilişkin olarak, usûlsüzlükleri önleyici, eğitici ve rehberlik yaklaşımını ön plana çıkaran bir anlayışla, Bakanlığın görev ve yetkileri çerçevesinde denetim, inceleme ve soruşturmalar yapmak." maddesinin atıf yapılmış olan yasal belgesine göre fazla ifade edildiği ve "Özel Eğitim, Rehberlik ve Danışma Hizmetleri Genel Müdürlüğünün 2009/09 sayılı genelgesi" ifadesindeki belgenin hatalı ifade edildiği tespit edilmiştir. Araştırmalar ve incelemeler sonucunda rehberde tespit edilmiş olan hatalar, denetim ve rehberlik faaliyetleri gerçekleştirilirken yapılabilecek olan başka hatalara neden olabilir. Denetim ve rehberlik faaliyetlerinin doğru ve eksiksiz bir şekilde gerçekleştirilebilmesi için rehber hazırlama sürecinde bu fazlalık veya hatalara ilişkin kontroller ve değerlendirmeler yapılmalıdır. Araştırmacılar, ortaya çıkan bu sorunlara yönelik yeni çalışmalar yürütebilirler.

Rehberin "tanımlar" bölümünde "denetim" ve "rehberlik" kavramlarının kullanımında; anlamının dışında kullanma ya da kavramları birbirlerinin yerine kullanma gibi tutarsızlıklar tespit edilmiştir. Rehberlerdeki kavramların anlamları bağlamında kullanılması gereklidir.

Rehberde yer alan Rehberlik ve Denetim ilkeleri bölümünde eğitim denetimi alanyazınına göre eksiklikler olduğu tespit edilmiştir ve rehberdeki ifadelerin hiçbirinde bilimsel çalışmalara yapılmış gönderme olmadığı görülmüştür. Denetim alanını, bilimselleştirebilmek için daha fazla çalışma yapılması ve denetim rehberinde alanyazın olarak bu bilimsel kaynaklardan yararlanılması önerilmektedir. Araştırmacılar, denetim biliminin gelişmesine katkı sağlayabilmek için ve denetim alanını bilimsel temellere dayandırabilmek için bu alanda çalışabilirler. 


\section{KAYNAKLAR}

Akçay Güngör, A. (2020). Özel Öğrenci Etüt Eğitim Merkezi Rehberlik ve Denetim Rehberinin Yasal Belgeler ve Alanyazın Temelinde İncelenmesi. e-Uluslararası Eğitim Araştırmaları Dergisi, 11 (3) , 90-109. Retrieved from http://www.e-ijer.com/tr/pub/issue/58698/820632

Akyol, B., Yavuzkurt, T., \& Ulutaş, M. (2020). PISA Sınavında Başarılı Olan Ülkelerde (Singapur, Finlandiya ve Japonya) Yetişkin Eğitiminin Örgütlenmesi ve Türkiye Karşılaştırması. Dicle Üniversitesi Sosyal Bilimler Enstitü Dergisi.

Aslan, S., \& Bal E. (2014). Rehberlik ve Araştırma Merkezlerinin Örgütsel Analizi. Eğitim ve Bilim, 313-324.

Arslan, H., Sayın, S., (2017). Öğretmen ve Okul Yöneticilerinin Öğretmen Performans Değerlendirme

Sürecindeki Çoklu Veri Kaynakları İle İlgili Görüşleri ve Öz Değerlendirmeleri. Uluslararası Türkçe Edebiyat Kültür Eğitim Dergisi, 1222-1241.

Arslan, H., Sevinç, N., (2020), Okul Yöneticiliğinden Entelektüel Liderliğe, Ankara: Anı Yayıncılık.

Aydın, İ. (2006). Eğitim ve Öğretimde Etik. Ankara: Pegem A Yayıncılık.

Aydın, M. (2014). Çağdaş Eğitim Denetimi. Ankara: Gazi Kitabevi.

Beytekin, O. F., \& Tas, Ş. (2017). Ortaokul Müdürlerinin Öğretimsel Denetime İlişkin Görüşlerinin İncelenmesi. Turkish Studies, 115-128.

Creswell, W. J. (2003). Research design: Qualitative, quantitative, and mixed methods approaches. London: SAGE Publications.

Ekinci, A., \& Karakuş, M. (2011). İlköğretim Okullarında Müfettişlerce Yapılan Rehberlik ve Denetim Çalışmalarının İşlevselliği. Kuram ve Uygulamada Eğitim Bilimleri, 1849-1867.

Gökçe, F. (1994). Eğitimde Denetimin Amaç ve IIlkeleri. Hacettepe Üniversitesi Eğitim Fakültesi Dergisi, 73-78.

Halmatov, S. (2014). Türkiye'de Psikolojik Danışma ve Rehberliğin Gelişim Süreci. Erzurum.

Hoy, W.; Miskel, G. C. (1978). Educational Administration, Theory, Research, and Practice, New York: Random House.

MEB (2016). Rehberlik ve Araştırma Merkezleri Rehberlik ve Denetim Rehberi. Ankara

MEB (2017). Milli Eğitim Bakanlığı Teftiş Kurulu Yönetmeliği.

Memduhoğlu, H. B., \& Zengin, M. (2011). Çağdaş Eğitim Denetimi Modeli Olarak Öğretimsel Denetimin Türk Eğitim Sisteminde Uygulanabilirliği. Kuramsal Eğitimbilim Dergisi, 131-142.

Kadı, A., Beytekin, O. F., \& Arslan, H. (2016). Academic Dishonesty Tendencies and Values of Teacher Candidates. Journal of Higher Education and Science, 396-401.

Kahraman, H. (2020). Öğretmenevleri, Öğretmenevi ve Akşam Sanat Okulları Rehberlik ve Denetim Rehberinin Yasal Metinler ve Alanyazın Temelinde İncelenmesi. e-Uluslararası Eğitim Araştırmaları Dergisi, 11 (3) , 123-138. Retrieved from http://www.e-ijer.com/tr/pub/issue/58698/836759

Özkan, U. B. (2019). Eğitim Bilimleri Araştırmaları lç̧in Döküman Inceleme Yöntemi. Ankara: PEGEM AKADEMI.

Ölmez Ceylan, Ö, Algam, E. (2020). i̇l/ilçe Milli Eğitim Müdürlükleri Denetim Rehberinin Yasal Belgeler ve Alanyazın Temelinde İncelenmesi. e-Uluslararası Eğitim Araştırmaları Dergisi, 11 (3) , 179-198 . Retrieved from http://www.e-ijer.com/tr/pub/issue/58698/831894

Özdemir, N, Altuntaş, F. (2020). Denetimde Standartlaşma Çabaları: Motorlu Taşıt Sürücüleri Kursu Denetim Rehberi Örneği. e-Uluslararası Eğitim Araştırmaları Dergisi, 11 (3) , 79-89. Retrieved from http://www.e-ijer.com/tr/pub/issue/58698/807767

Öztürk, Ş. (2009). ilköğretim Okullarının Kurum Denetiminde Karşılaşılan Sorunlara iliş̧kin Müfettiş ve Okul Müdürü Görüşleri (Kütahya ili Örneği). Muğla: Muğla Üniversitesi Sosyal Bilimler Enstitüsü.

Resmi Gazete (2016). Milli Eğitim Bakanlığı Rehberlik ve Psikolojik Danışma Hizmetleri Yönetmeliği.

Resmi Gazete (2018). 10/07/2018 Tarihli 30474 Sayılı Resmi Gazete Cumhurbaşkanlı̆̆ı Teşkilatı Hakkında Cumhurbaşkanlığı Kararnamesi.

Resmi Gazete (2020). 31213 Sayılı Milli Eğitim Bakanlı̆ı Rehberlik ve Psikolojik Danışma Hizmetleri Yönetmeliği.

Resmi Gazete (2017). Milli Eğitim Bakanlığı Rehberlik ve Psikolojik Danışma Hizmetleri Yönetmeliği.

Resmi Gazete. (2020). Milli Eğitim Bakanlığı Rehberlik ve Psikolojik Danışma Hizmetleri Yönetmeliği. Ankara.

Resmi Gazete (2020). Özel Eğitim Hizmetleri Yönetmeliği.

Sağlam, A. Ç., \& Aydoğmuş, M. (2016). Gelişmiş ve Gelişmekte Olan Ülkelerin Eğitim Sistemlerinin Denetim Yapıları Karşılaştırılığında Türkiye Eğitim Sisteminin Denetimi Ne Durumdadır? Uşak Üniversitesi Sosyal Bilimler Dergisi, 17-38.

Seven, M. A., \& Engin, A. O. (2012). Eğitimde Rehberliğin Önemi. EKEV Akademi Dergisi, 247-259. 
Tonbul, Y, Ata Çiğdem, F. (2020). Bilsem Denetim Rehberinin Yasal Belgeler ve Alanyazın Temelinde İncelenmesi. e-Uluslararası Eğitim Araştırmaları Dergisi, 11 (3) , 36-62. Retrieved from http://www.eijer.com/tr/pub/issue/58698/804118

Tonbul, Y, Ödemiş Keleş, N. (2020). Mesleki Eğitim Merkezleri Rehberlik ve Denetim Rehberi" nin Yasal Belgeler ve Alanyazın Temelinde Tutarlılığının İncelenmesi. e-Uluslararası Eğitim Araştırmaları Dergisi, 11 (3) , 139-153. Retrieved from http://www.e-ijer.com/tr/pub/issue/58698/803653

Toprakçı, E. (2008). Sınıfa Dayalı Yönetim. Ankara: Pegem Yayınları.

Toprakçı, E., \& Güngör, A. A. (2014). Türkiye'deki Siyasal Partilerin Eğitim Politikaları. Educational Policy Analysis and Strategic Research, 5-35.

Toprakçı, E., Beytekin, O., F., Doğan, M. (2018). Yargıtayın Özel Öğretim Kurumlarına İlişkin Verdiği Kararların İncelenmesi. Turkish Studies, 13(19), 1781-1795.

Toprakçı, E., Oflaz, G., Dağdeviren, İ.,Türe, E. (2010). Eğitim Fakültesi Öğretim Elemanlarının Bilim Anlayışları Temelinde Eğitimin Bilimliliği. Bilim ve Ütopya, 45-56.

Toprakçı, E.; Taş, Ş. (2020). Yargıtay'ın okul müdürlerine ilişkin verdiği kararların incelenmesi. E- Uluslararası Eğitim Araştırmaları Dergisi, 11(1), s.20-40.

Toprakçı, E, Bakır, D. (2020). Yabancı, Azınlık ve Milletlerarası Okullar Denetim Rehberinin Yasal Belgeler ve Alanyazın Temelinde İncelenmesi. e-Uluslararası Eğitim Araştırmaları Dergisi, 11 (3) , 16-35. Retrieved from http://www.e-ijer.com/tr/pub/issue/58698/800326

Toprakçı, E, Özerten, K. (2020). Özel Öğrenci Yurtları Rehberlik ve Denetim Rehberinin Yasal Belgeler ve Alanyazın Temelinde İncelenmesi. e-Uluslararası Eğitim Araştırmaları Dergisi, 11 (3) , 199-216. Retrieved from http://www.e-ijer.com/tr/pub/issue/58698/817509

Weber, R. P. (1990). Basic Content Analysis. London: SAGE.

Yıldııım, A., \& Şimşek, H. (2018). Sosyal Bilimlerde Nitel Araştırma Yöntemleri. Seçkin Yayıncılık.

Yıldız, N. G., Melekoğlu, M. A., \& Paftalı, A. T. (2016). Türkiye'de Özel Eğitim Araştırmalarının İncelenmesi. Elementary Education Online, 1076-1089. 


\section{The Investigation of the Guidance and Research Centers' Supervisory Guideline}

\author{
Doç. Dr. Osman Ferda Beytekin \\ Ege Üniversitesi- Turkey \\ beytekin.ferda@gmail.com
}

\author{
Elif Kaynar (Graduate) \\ Ministiry of National Education-Turkey \\ elf.kaynar@gmail.com
}

\begin{abstract}
The aim of this study is to examine the Guidance and Research Centers' Supervision Guide on the basis of legal documents and literature. The document analysis model, one of the qualitative research methods, was used in the study. The study document of the research is the Guidance and Supervision Guide of the Guidance and Research Centers. The data were analyzed using the content analysis technique. When the findings of the research were examined; it was determined that the Guidance and Psychological Counseling Services Regulation and Special Education Services Regulation referred by the guide were out of date. And it has been determined that the abolition of the article "Application of various psychological measurement tools according to scientific standards according to the quality of the service to be provided (MEB Guidance and Psychological Counseling Services Regulation Art. 30 / d)". This finding could be interpreted as the main reason for the inconsistency in the guideline. It was concluded that Guidance and Research Centers Supervision Guide was mostly consistent with the literature, although it was not updated. Apart from this, it has been determined that there are no expressions regarding the concept of ethics and the implementation of ethical values in the content of the guide.
\end{abstract}

Keywords: Educational supervision, Guidance and Research Center, Supervision Guide

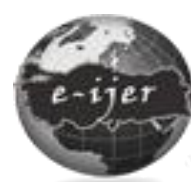

E-International Journal of Educational Research, Vol: 12, No: 1, 2021, pp. 89-103

DOI: 10.19160/jier.840891

Received: 14.12 .2020 Accepted: 04.03.2021

\section{Suggested Citation:}

Beytekin, O. F. Ve Kaynar, E. (2021). The Investigation of the Guidance and Research Centers' Supervisory Guideline. EInternational Journal of Educational Research, Vol: 12, No: 1, 2021, pp. 89-103, DOI: 10.19160/ijer.840891 


\section{EXTENDED ABSTRACT}

Problem: The aim of this study is to analyze the Guidance and Research Centers' Supervision Guide on the basis of literature knowledge and to identify the deficiencies in the guide and contribute to the education in theory and practice in Turkey. In the literature, no scientific study on supervision guides has been found. In this research, it is aimed to examine the consistency, appropriateness and up-to-dateness of the Guidance and Research Centers Supervision Guide within the framework of the literature and legal documents.

Method: In this study, document analysis method, one of the qualitative research designs, was used. Document review requires the study and interpretation of data to review and evaluate both printed and electronic material. Analytical processing in document review includes finding, selecting, evaluating, interpreting and synthesizing the data in the documents. Online media and books were used to access legal documents. The originality of the information obtained has been confirmed by expert opinions and online facilities. In the study, codes, categories and themes were reached by correlating the data. In this process, sources, colleague confirmation and expert opinion were consulted in cases of conflict. The supervision guide examined in this study was a legal document and its being legal ensures the validity of the study. In the study, it was tried to provide validity and reliability by including the exact quotations from the legal document and reporting in detail.

Findings: When the codes of the category of the supervision guide $(n=108)$ inconsistency with the legal documents were examined, the code of being outdated according to the legal basis ( $\mathrm{n}$ $=48$ ) was preferred when the statement in the guide or the legal document accompanying this statement was out of date or abolished. This code reveals that the guide should be updated, showing that it is out of date. Legal basis uncertainty $(n=32)$ code is used when there are cases where there is no explicit reference to the legal document on the subject. No reference is made to any legal document regarding the relevant statement in the example. Four codes, namely "Lack of Content", "Inconsistency", "Conceptual Inconsistency" and "Inconsistency", were identified in the category of the inconsistency of the supervision guide with the literature. Thanks to this code, which emerged as a result of the review of the guide, it can be said that the guide was only adhered to the legislation in addition to the purpose of producing scientific knowledge. In the guideline, the concept of "Ethics", which should be taken into consideration while guiding and supervising, and found in the literature, is in principle lacking. It can be said that the officers responsible for preparing the guide are lacking in the basis of the literature. Including a principle not included in the literature in the supervision guide causes an expression that contradicts with the literature.

Suggestions: Researchers and practitioners can work and update the guideline consistently to increase the consistency of the guideline. The Guidance and Research Centers Guidance and Supervision Guide needs to be changed in line with the changing and updated legal documents. In order to keep the guides up-to-date, a database created by the researchers responsible for the audit guides can be established. The database will make it easier to access and update legal documents. A committee can be established to examine the legal documents to be used in the preparation process. It may be suggested to follow the laws of different countries on supervising in order to facilitate the work of researchers and to prepare coherent, scientific guidelines. During the guideline preparation process, checks and evaluations should be made regarding redundancy or errors. It is recommended to do more studies in the field of audit and to use these scientific sources in the supervision guide. 